\title{
NEW FRONTIERS OF SEISMIC SURVEYING IN ANTARCTICA: THE MAPPING OF A THIN LAYER AT THE BASE OF ICE STREAM B (Abstract)
}

by

\author{
Donald D. Blankenship
}

(Geophysical and Polar Research Center, University of Wisconsin-Madison, Madison, WI 53706, U.S.A.)

\begin{abstract}
The recent availability of high resolution (greater than $250 \mathrm{~Hz}$ ) seismic recording equipment in the Antarctic field environment has allowed the acoustical mapping of a previously unobserved subglacial phenomenon. This phenomenon is a thin (less than $10 \mathrm{~m}$ ), yet continuous, layer at the base of Ice Stream B in West Antarctica. Discovery of this layer came during the 1983-84 austral summer in a seismic reflection survey that covered approximately $10 \mathrm{~km}^{2}$ near the Upstream B field camp $\left(83^{\circ} 31^{\prime} \mathrm{S}, 138^{\circ} 05^{\prime} \mathrm{W}\right)$. Although analysis of the seismic data is at a preliminary stage, there is the possibility that this feature could be a basal "lubricating" layer; some sort of lubrication is of course necessary to explain the very large horizontal velocities of these ice streams.

During the seismic reflection survey on Ice Stream B,
\end{abstract}

a new digital seismic recording system, developed by the Geophysical and Polar Research Center, was used for the first time under field conditions. Resolution of such a thin layer was possible only because of the very large bandwidth $(0-600 \mathrm{~Hz})$ and dynamic range $(84 \mathrm{~dB})$ of this device; this bandwidth is about twice that possessed by commercially available seismic recorders. In addition, a new level of portability (i.e. a weight of $40 \mathrm{~kg}$ and a power requirement of 90 watts), which should make this device usable in virtually any Antarctic field situation, has been achieved by the application of advanced recording technologies. The portability of this digital seismic recorder, when combined with its large bandwidth and dynamic range, should result in the resolution of a whole new class of intra- and subglacial phenomena, of which the thin basal layer of Ice Stream B is the first example. 